\title{
Ekspresi Protein Deleted in Colorectal Cancer (DCC) dan p53 pada Keganasan Kolorektal
}

\author{
Ida Bagus Budhi Surya Adnyana, ${ }^{1}$ Reno Rudiman ${ }^{2}$ \\ ${ }^{1}$ Bagian Imu Bedah Fakultas Kedokteran Sebelas Maret Surakarta/Rumah Sakit Umum Daerah Dr. Moewardi \\ Surakarta, ${ }^{2}$ Subbagian Bedah Digestif Fakultas Kedokteran Universitas Padjadjaran/Rumah Sakit Umum Pusat \\ Dr Hasan Sadikin Bandung
}

\begin{abstract}
Abstrak
Angka kejadian keganasan kolorektal pada usia muda semakin meningkat, tetapi belum ada data yang cukup menjelaskan mengenai hal tersebut, termasuk mutasi gen yang berperan. Tujuan penelitian mengetahui apakah ekspresi protein DCC dan p53 berperan pada keganasan kolorektal usia kurang dari 40 tahun. Dilakukan pemeriksaan imunohistokimia di Departemen Patologi Anatomi Fakultas Kedokteran Universitas Padjadjaran/ Rumah Sakit Umum Pusat Dr. Hasan Sadikin Bandung periode Januari sampai Mei 2011 untuk melihat ekspresi protein DCC dan p53 pada sediaan blok parafin penderita keganasan kolorektal kelompok usia $<40$ tahun dan usia $>40$ tahun. Bahan pemeriksaan dikumpulkan mulai bulan Januari sampai Mei 2011. Hasil penelitian menunjukkan bahwa pada keganasan kolorektal usia $<40$ tahun lebih banyak yang tidak didapatkan ekspresi kedua protein tersebut, 9 kasus pada kelompok usia $>40$ tahun, sedangkan pada usia lebih dari 40 tahun hanya ditemukan pada 2 kasus. Simpulan, pada sebagian besar kasus keganasan kolorektal usia $<40$ tahun, protein DCC dan p53 sudah tidak terekspresi. [MKB. 2017;49(3):186-91]
\end{abstract}

Kata kunci: Ekspresi DCC, ekspresi p53, keganasan kolorektal, usia

\section{Deleted in Colorectal Cancer (DCC) and p53 Protein Expressions in Colorectal Cancer}

\begin{abstract}
The incidence of colorectal cancer in young patients is currently increasing; however, no adequate data available to explain the increase, including the gene mutation involved in these cancer. This study aimed to discover the DCC and p53 protein expressions that play a role in colorectal cancer in people under 40 years old. Immunohistochemical examination was performed at the Department of Anatomy Pathology Faculty of Medicine of Universitas Padjadjaran/Dr. Hasan Sadikin General Hospital Bandung in the period of January to May 2011 to look into DCC and p53 expressions in paraffin blocks of colorectal malignancy patients in the age group of $<40$ and $>40$ years old. The examination specimens were collected in the period of January to May 2011. The results of the study showed that in colorectal malignancy in $<40$ years old patients, the expression of the two proteins was rarely found while in the age group of 40 years old, the expressions were only found in 2 cases. It is concluded in most cases of colorectal cancer in the <40 years old group, the DCC and p53 are already not expressed. [MKB. 2017;49(3):186-91]
\end{abstract}

Key words: Age, colorectal cancer, DCC expression, p53 expression

Korespondensi: Ida Bagus Budhi Surya Adnyana, dr., Sp.B(K)BD, M.Kes., Bagian Imu Bedah Fakultas Kedokteran Sebelas Maret Rumah Sakit Umum Daerah Dr. Moewardi Surakarta, E-mail: budhi_suryaadnyana@yahoo.com 


\section{Pendahuluan}

Karsinoma kolorektal merupakan keganasan saluran pencernaan yang tersering ditemukan. Pada tahun 2010 telah didapatkan 39.670 kasus baru keganasan kolorektal di Amerika Serikat. ${ }^{1}$ Karsinoma kolorektal merupakan penyebab kematian urutan kedua setelah kanker payudara di Amerika Serikat., ${ }^{1,2}$

Risiko mendapatkan karsinoma kolorektal mulai meningkat setelah usia 40 tahun dan meningkat pada usia 50-55 tahun, selanjutnya risiko meningkat menjadi dua kali lipat setiap dekade berikutnya. ${ }^{3-6}$ Saat ini di Rumah Sakit Dr. Hasan Sadikin Bandung dalam satu tahun terakhir telah ditemukan 100 kasus keganasan kolorektal berbagai stadium dan 50\% kasus berusia kurang dari 40 tahun.

Karsinoma kolorektal merupakan kasus kelainan genetik, didapatkan perubahan genetik yang berakibat pertumbuhan sel yang progresif. ${ }^{5-7}$ Secara garis besar, gen yang berperan untuk terjadi karsinoma kolorektal dikelompokkan menjadi tiga, di antaranya onkogen (K-ras), tumor supresor gen (adenomatous poliposis coli $(A P C), p 53$, deleted in colorectal cancer $(D C C)$ ), dan mismatch repair gen (Hmsh2, Hmlh1, Hpms1, Hpms2). ${ }^{2,8,9}$

Mutasi gen tersebut dapat mengakibatkan keganasan kolorektal. Pada tahun 1990, Fearon dan Vogelstein, seperti dikutip oleh Kelli ${ }^{2}$ yang sudah memperkenalkan patogenesis karsinoma kolorektal dan dinyatakan bahwa paling tidak ditemukan 5 mutasi gen. Secara histopatologi melalui pemeriksaan imunohistokimia, mutasi gen yang berperan dalam keganasan kolorektal dapat diketahui dengan cara melihat ekspresi proteinnya. $^{10-12}$

Meskipun ini sebagai kasus multifaktorial dapat ditinjau dari biologi molekuler keganasan kolorektal ini terjadi akibat mutasi beberapa gen seperti gen $A P C, K$-ras, DCC, dan $p 53 .^{3-5}$ Progresivitas dan kemungkinan penyebaran keganasan kolorektal ditentukan oleh adhesi antarselnya. Apabila adhesi antarsel mulai lemah kemungkinan besar akan terjadi penyebaran, baik melalui kelenjar getah bening maupun melalui aliran darah (secara limfogen maupun hematogen). ${ }^{8}$ Di antara gen yang berperan dalam keganasan kolorektal ini hanya gen $D C C$ yang mempunyai peranan tersebut. ${ }^{11,12}$

Di dalam tahap perkembangan adenoma yang telah lanjut (late adenoma) menjadi adenokarsinoma, gen p53 yang mengalami mutasi memegang peranan yang penting, berupa kegagalan dalam proses transkripsi. ${ }^{5}$ Penelitian peran mutasi gen p53 dalam perkembangan keganasan kolorektal pada populasi secara umum telah dilakukan, terdapat mutasi gen ini dapat ditemukan pada 52\% kasus dan angka harapan hidup lebih rendah pada kasus yang mengalami mutasi gen $p 53 .^{13-15}$

Dari beberapa penelitian yang telah dilakukan dan dilaporkan dalam jurnal, dinyatakan bahwa angka kejadian keganasan kolorektal pada usia $<40$ tahun semakin meningkat. ${ }^{16,17}$

Tujuan penelitian ini adalah mengetahui apakah ekspresi protein DCC dan p53 berperan pada keganasan kolorektal usia kurang dari 40 tahun.

\section{Metode}

Penelitian ini merupakan penelitian deskriptif dan data diambil secara retrospektif. Bahan pemeriksaan yang digunakan adalah 30 sediaan blok parafin dari penderita adenokarsinoma kolorektal stadium III dikumpulkan mulai periode Januari sampai Mei 2011 dan dikirim ke Bagian Patologi Anatomi Fakultas Kedokteran Universitas Padjadjaran/Rumah Sakit Umum Pusat Dr. Hasan Sadikin Bandung. Dilakukan pemeriksaan imunohistokima pada sediaan blok parafin yang telah ada. Subjek penelitian dikelompokkan menjadi 4, yaitu kelompok didapatkan ekspresi kedua protein, kelompok tanpa ekspresi kedua protein, dan dua kelompok yang hanya terdapat ekspresi pada salah satu proteinnya. Pemeriksaan imunohistokimia ini dilakukan untuk melihat ada atau tidaknya ekspresi protein DCC pada sediaan blok parafin, untuk pewarnaan digunakan antibodi DCC dan p53 (Santa Cruz Biotechnology, Inc). Teknik yang digunakan adalah prosedur Streptavidin-Biotin yang terdiri atas 5 tahap.

Pada tahap I dilakukan pencucian sediaan blok parafin memakai larutan xilen, alkohol absolut, alkohol 95\% selama 5 menit, dilakukan 2 kali pencucian. Berikutnya, pada tahap II digunakan larutan $\mathrm{H}_{2} \mathrm{O}_{2}$ /metanol yang kemudian dibilas dengan air suling dan larutan bufer selama 10 menit untuk menghilangkan aktivitas peroksidase endogen. Selanjutnya, pada tahap III diberikan antigen dan dibilas dengan larutan bufer selama sepuluh menit. Setelah diberikan antigen, perlu menghilangkan pewarnaan dasar nonspesifik pada tahap IV dengan blocking solution dan larutan bufer selama 10 menit. Pada tahap terakhir dilakukan pewarnaan imunohistokimia dengan pemberian antibodi primer yang bervariasi. 
Ida Bagus B. S. Adnyana: Ekspresi Protein Deleted in Colorectal Cancer (DCC) dan p53 pada Keganasan Kolorektal

Tabel Ekspresi Protein DCC dan p53 berdasar atas Jenis Kelamin dan Lokasi Tumor

\begin{tabular}{clcccc}
\hline \multirow{2}{*}{ Variabel } & \multicolumn{2}{c}{ Ekspresi DCC } & \multicolumn{2}{c}{ Ekspresi p53 } \\
\cline { 3 - 6 } & & Positif & Negatif & Positif & Negatif \\
\hline \multirow{2}{*}{$\begin{array}{c}\text { Jenis } \\
\text { kelamin }\end{array}$} & Laki-laki & 5 & 5 & 6 & 10 \\
& Perempuan & 6 & 14 & 8 & 6 \\
& Caecum & 1 & 0 & 0 & 1 \\
& Kolon asendens & 2 & 0 & 1 & 1 \\
& Kolon desendens & 0 & 1 & 1 & 0 \\
& Kolon transversum & 2 & 3 & 5 & 13 \\
& Rektum & 6 & 14 & 7 & 0 \\
\end{tabular}

Ekspresi protein DCC dinilai positif apabila distribusi intensitas pewarnaan imunoreaktif yang diberikan bermanifestasi pada membran dan sitoplasma. Pemeriksaan mempergunakan mikroskop cahaya dengan pembesaran 100x.

Ekspresi protein p53 dinilai positif apabila distribusi intensitas pewarnaan imunoreaktif yang diberikan bermanifestasi pada inti sel. Pemeriksaan menggunakan mikroskop cahaya pembesaran 100x.

Analisis chi-kuadrat untuk melihat apakah terdapat hubungan ekspresi protein DCC dan p53 dengan keganasan kolorektal pada usia $<40$ tahun. Untuk menguji tujuan penelitian ini dilakukan analisis statistik dengan bantuan perangkat lunak SPSS 13.

\section{Hasil}

Dari 30 subjek penelitian, berdasar atas lokasi ditemukan keganasan kolorektal paling banyak di rektum pada 20 kasus (Tabel 1).

Dari pemeriksaan imunohistokimia yang dilakukan pada 30 sampel penelitian, didapatkan empat kemungkinan kelompok ekspresi protein. Gambar memperlihatkan keempat kelompok tersebut dalam keseluruhan populasi subjek penelitian dan dibandingkan antara kedua kelompok usia. Ekspresi protein DCC dan p53 lebih banyak didapatkan pada kelompok usia $>40$ tahun, 9 kasus pada kelompok usia <40 tahun tidak didapatkan ekspresi kedua protein tersebut.

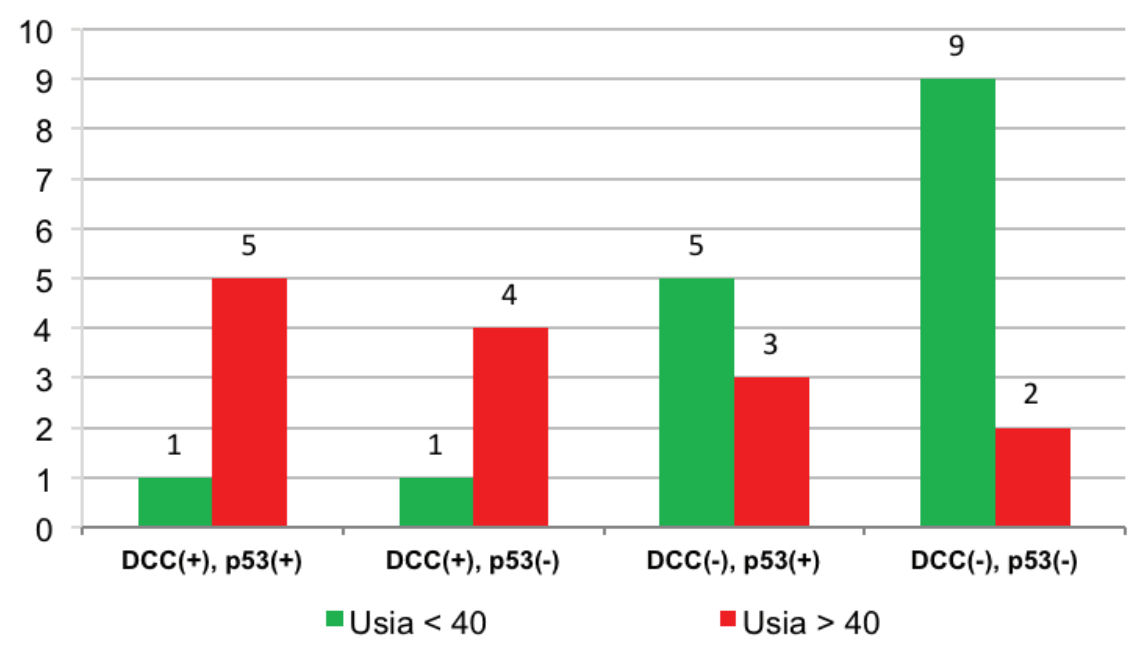

Gambar 1 Perbandingan Ekspresi Protein antara Dua Kelompok Usia 

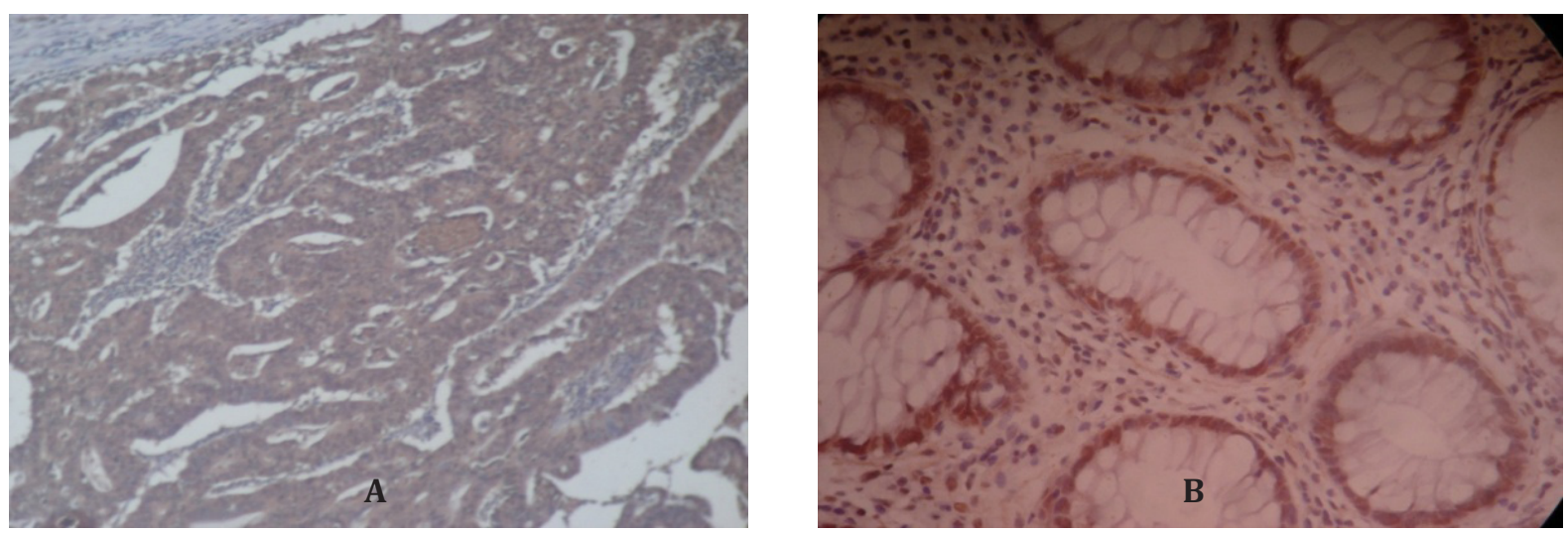

Gambar 2 Ekspresi Protein DCC dan p53. (A) Ekspresi Protein DCC, (B) Ekspresi Protein p53

Berdasar analisis statistik didapatkan bahwa keganasan kolorektal pada kelompok usia $<40$ tahun mempunyai hubungan yang bermakna secara statistik dengan ekspresi protein DCC, sedangkan ekspresi protein p53 tidak terdapat hubungan yang bermakna.

\section{Pembahasan}

Sebanyak 30 subjek penelitian masing-masing terdiri atas 15 subjek penderita keganasan kolorektal usia $<40$ tahun dan 15 subjek $>40$ tahun. Sebanyak 9 kasus keganasan kolorektal usia $<0$ tahun tidak didapatkan ekspresi protein baik protein DCC maupun p53, sedangkan pada kelompok usia $>40$ tahun, tidak terdapat ekspresi protein tersebut hanya didapatkan pada dua kasus. Kedua ekspresi protein gen $D C C$ dan $p 53$ ini yang merupakan gen supresor tumor sangat diperlukan untuk menghambat progresivitas keganasan kolorektal. Keganasan kolorektal yang ditemukan pada usia muda cenderung lebih progresif, ${ }^{16,17}$ dapat dilihat dari lebih banyak kasus yang tidak didapatkan ekspresi protein pada penderita usia $<40$ tahun.

Ditinjau dari sisi psikoneuroimunologi, pada kasus keganasan kolorektal usia muda lebih banyak disertai dengan semakin tinggi stresor yang diikuti dengan semakin menurun imunitas pada kelompok usia tersebut sehingga supresor terhadap pertumbuhan tumor semakin rendah dan tumor akan berkembang semakin progresif. ${ }^{8}$

Pada penelitian ini, ekspresi protein DCC dan p53 yang dilihat melalui pemeriksaan imunohistokimia ternyata tidak dipengaruhi oleh variabel penelitian yang lain sehingga variabel perancu seperti jenis kelamin dan lokasi keganasan kolorektal tidak memengaruhi hasil penelitian ini. Beberapa penelitian lain yang telah dilaporkan dalam jurnal, baik pada populasi umum maupun kelompok penderita usia muda, tidak didapatkan pengaruh jenis kelamin dan lokasi keganasan kolorektal tersebut pada ekspresi kedua protein ini. ${ }^{4,7,11,13}$

Penelitian Jen dkk. ${ }^{18}$ dinyatakan bahwa pada populasi secara umum, pada stadium yang sama, tidak terdapat ekspresi protein DCC pada keganasan kolorektal berhubungan dengan progresivitas keganasan tersebut. Penelitian lain pernah melaporkan tidak terdapat ekspresi protein tersebut berhubungan dengan respons pemberian kemoterapi..$^{10,12,14}$

Empat kasus keganasan kolorektal pada usia $<40$ tahun hanya didapatkan salah satu ekspresi protein gen supresor tumor (ekspresi protein DCC positif dan ekspresi protein p53 negatif atau sebaliknya). Meskipun dilakukan penelitian pada stadium yang sama (stadium III), ternyata masih mungkin didapatkan variasi hasil pemeriksaan imunohistokimia ekspresi protein tersebut pada setiap subjek yang diteliti. Penelitian ini masih dapat dikembangkan untuk melihat bagaimana progresivitas keganasan kolorektal terutama pada kasus yang hanya didapatkan ekspresi protein salah satu gen supresor tumor. Penelitian ini belum dapat menyimpulkan ekspresi protein mana yang lebih berperan untuk mencegah progresivitas keganasan kolorektal, khususnya pada kasus penderita usia muda.

Meskipun dalam kepustakaan dinyatakan bahwa pada keganasan kolorektal sporadik, ekspresi kedua protein tersebut hanya terjadi pada $<50 \%$ kasus, $^{4,5}$ tetapi dalam penelitian ini, kelompok penderita keganasan kolorektal usia $<40$ tahun mempunyai karakteristik yang 
berbeda. Sebanyak 9 kasus tidak didapatkan ekspresi protein DCC dan p53, sedangkan enam kasus hanya didapatkan ekspresi salah satu protein tersebut.

Penelitian ini dilakukan untuk mengetahui peranan ekspresi dua gen supresor tumor pada keganasan kolorektal, karena kedua gen tersebut yang berperan dalam menghambat progresivitas perkembangan keganasan kolorektal. Penelitian ini dilakukan pada tingkat protein, bukan tingkat gen yang mengalami mutasi, dengan asumsi bahwa ekspresi protein melalui pemeriksaan imunohistokimia sediaan blok parafin dikatakan positif minimal didapatkan $10 \%$ ekspresi dari setiap sediaan. Hal ini menggambarkan bahwa apabila protein masih terekspresi, maka gen tersebut masih dapat berperan dalam fungsinya sebagai gen supresor tumor. ${ }^{10-12}$ Derajat mutasi yang terjadi berdasar atas hasil pemeriksaan imunohistokimia tersebut, masih diperlukan pemeriksaan lain di tingkat genetik untuk lebih dapat menjelaskan hal tersebut.

Simpulan, pada sebagian besar kasus keganasan kolorektal usia $<40$ tahun tidak didapatkan ekspresi protein DCC dan p53.

\section{Daftar Pustaka}

1. National Comprehensive Cancer Network Clinical Practice Guidelines in Oncology. Rectal cancers [diunduh 12 September 2016]. Tersedia dari: www.nccn.org

2. Kelli BM. Colon, rectum and anus. Dalam: Brunicardi FC, Anderson D, Dunn DL, penyunting. Schwartz's principles of surgery. Edisi ke-10. New York: McGraw-Hill Medical Publising; 2014. hlm. 1047-102.

3. Potter MA. Principles of the surgical management of cancer. Dalam: Garden JO, penyunting. Principles and practice of surgery. Edisi ke-7. Edinburg: Elsevier; 2017. hlm. 86-98.

4. Dutt P, Stambolic V. Oncogenes and tumor supressor genes. Dalam: Tannock I, Hill R, Bristow R, Herrington L, penyunting. The basic science of oncology. Edisi ke-5. New York: McGraw Hill; 2013. hlm. 147-73.

5. Birbeck FK. Pathology and staging of rectal cancer. Dalam: Audisio RA, Gerghty JG, Longo $\mathrm{WE}$, penyunting. Modern management of cancer of the rectum. London: SpringerVerlag Limited; 2001. hlm. 7-14.

6. Debas HT. Small and large intestine. Dalam: Gastrointestinal surgery: pathophysiology and management. New York: Springer-Verlag
Inc; 2004. hlm. 296-300.

7. Wright M, Beaty JS, Ternent CA. Moleculare markers for colorectal cancer. Dalam: Langenfeld SJ, penyunting. Surgical clinics of north america advances in colorectal neoplasia. Volume 97. Philadelpia: Elsevier; 2017. hlm. 683-700.

8. Sudiana Ketut I. Patobiologi molekuler kanker. Jakarta: Salemba Medika; 2008.

9. Cohan J, Varma MG. Large intestine. Dalam: Doherty GM, penyunting. Current surgical diagnosis and treatment. Edisi ke-14. Boston: McGraw-Hill Companies Inc; 2015. hlm. 686-710.

10. Aschele C, Debernardis D, Lonardi S, Bandelloni R, Casazza S, Monfardini S, dkk. Deleted in colon cancer protein expression in colorectal cancer metastases: a major predictor of survival in patients with unresectable metastatic disease receiving palliative fluorouracil-based chemotherapy. J Clin Oncol. 2004;22(18):3758-65.

11. Mehlen P, Fearon ER. Role of the dependence receptor DCC in colorectal cancer pathogenesis. J Clin Oncol. 2004;22(16): 3420-8.

12. Ince WL, Jubb AM, Holden SN, Holmgren EB, Tobin P, Sridhar M, dkk. Association of k-ras, b-raf, and p53 status with the treatment effect of bevacizumab. J Natl Cancer Inst. 2005;97(13):981-9.

13. Conlin A, Smith G, Carey FA, Wolf CR, Steele RJ. The prognostic significance of K-ras, p53 and APC mutation in colorectal carcinoma. Gut. 2005;54:1283-6.

14. Kandioler D, Pilat N, Kappel S, Gruenberger T, Laengle F, Mittlboeck M, dkk. A prospective study of the interaction between p53 genotype and overall survival in patients with colorectal cancer liver metastases with and without neoadjuvant therapy (oxaliplatin and capecitabine/5-FU): A p53 reseach group study. J Clin Oncol. 2009; 27(15S);e15003.

15. Mollevi DG, Serrano T, Ginesta MM, Valls J, Torras J, Jaurrieta E, dkk. Mutations in TP53 are a prognostic factor in colorectal hepatic metastases undergoing surgical resection. 2007;28(6):1241-6.

16. Hill DA, Furman WL, Billups CA, Riedley SE, Cain AM, Rao BN, dkk. Colorectal carcinoma in childhood and adolescence: a clinicopathologic review. J Clin Oncol. 2007;25(36):5808-14.

17. Liang $\mathrm{H}$, Wang XN, Wang BG, Pan Yuan, Liu Ning, Wang DC, dkk. Prognostic factors 
Ida Bagus B. S. Adnyana: Ekspresi Protein Deleted in Colorectal Cancer (DCC) dan p53 pada Keganasan Kolorektal

of young patients with colon cancer after surgery. World J Gastroenterol. 2006;12(9): 1458-62.

18. Jen J, Kim H, Piantadosi S, Liu ZF, Lewitt RC,
Pertti S, dkk. Allelic loss of chromosome 18q and prognosis in colorectal cancer. N Engl J Med. 1994;331(4):213-21. 